\title{
Handbooks in Analytical Chemistry
}

DOI: $10.1134 / \mathrm{S} 1061934809100013$

Older Russian analysts still remember the handbook by Yu.Yu. Lur'e, published several times, and that contains a lot of helpful information [1]. However, times have changed, analytical chemistry has been enriched by new methods and directions, and the requirements of reference books have correspondingly increased. Modern handbooks should cover much that was included in the handbooks by Lur'e and A.I. Lazarev with coauthors [2]. This is particularly true for physical and biochemical methods of analysis, the provision of the quality of analysis (metrology, standard samples of composition, etc.), and attention to new objects of analysis. Meanwhile, modern handbooks in Russian are virtually absent.

Books with the name "Handbook" have been issued, but they can hardly be considered as true handbooks meeting modern requirements. Thus, "A New Handbook on Analytical Chemistry," published in St. Petersburg in three volumes [3] contains big articles, actually chapters or even micromonographs on a number of methods and directions of chemical analysis. The sections devoted to analytical chemistry are available in a number of general chemical handbooks; such sections are contained in the "Great Chemical Handbook" [4] and in other editions $[5,6]$. However, these handbooks include basically the traditional material useful in performing chemical methods of analysis.

Handbooks were issued on terms $[6,7]$ and on other specific aspects of analytical chemistry; however, they actually do not solve the problem of collecting all the data necessary for a practical analyst in everyday work under one cover.

This is the task: To try to create such a handbook.

\section{REFERENCES}

1. Lur'e, Yu.Yu., Spravochnik po analiticheskoi khimii (Handbook on Analytical Chemistry), Moscow: Khimiya, 1989.

2. Lazarev, A.I., Kharlamov, I.P., Yakovlev, P.Ya., and Yakovleva, E.F., Spravochnik khimika-analitika (Handbook for Analytical Chemists), Moscow: Metallurgiya, 1976.

3. Novyi spravochnik khimika $i$ tekhnologa. Analiticheskaya khimiya (A New Handbook of Chemist and Engineer: Analytical Chemistry), St. Petersburg: Mir i sem'ya, 2002, part 1.

4. Volkov, A.I. and Zharskii, I.M., Bol'shoi khimicheskii spravochnik (Great Chemical Handbook), Minsk: Sovremennaya shkola, 2005.

5. Artemenko, A.I., Tikunova, I.V., and Malevannyi, V.A., Spravochnoe rukovodstvo po khimii (Handbook of Chemistry), Moscow: Vysshaya shkola, 2003.

6. Tikunova, I.V. and Artemenko, A.I., Khimiya. Kratkii spravochnik (Chemistry: a Quick Reference Book), Moscow: Vysshaya shkola, 2004.

7. Budnikov, G.K., Medyantseva, E.P., and Ulakhovich, N.A., Terminy $i$ osnovnye ponyatiya $v$ analiticheskoi khimii. Uchebno-metodicheskoe posobie (Terms and Basic Concepts in Analytical Chemistry: A Handbook), Kazan: Izd. Kazansk. Univ., 1991.

8. Ukazatel' osnovnykh terminov po analiticheskoi khimii na russkom i angliiskom yazykakh (Index of Key Terms in Analytical Chemistry in Russian and English), Moscow: VINITI, 1988. 